\title{
Pelatihan pencegahan intoksikasi kadmium pada pekerja bengkel las di Kota Mataram
}

\author{
Bayu Tirta Dirja1 ${ }^{*}$, Devi Rahmadhona ${ }^{2}$, Decky Aditya Zulkarnaen ${ }^{3}$ \\ ${ }^{1}$ Departemen Mikrobiologi, Fakultas Kedokteran, Universitas Mataram, Mataram, Indonesia \\ 2 Departemen Patologi Klinik, Fakultas Kedokteran, Universitas Mataram, Mataram, Indonesia \\ ${ }^{3}$ Departemen Anatomi, Fakultas Kedokteran, Universitas Mataram, Mataram, Indonesia
}

DOI: https://doi.org/10.29303/indra.v2i2.129

\section{Article Info}

Received : 09-09-2021

Revised : 29-09-2021

Accepted : 29-09-2021

\begin{abstract}
Cadmium (Cd) is a nephrotoxic heavy metal which endangers human health, especially welding workers. Cadmium can enter the body through inhalation of formed air pollutants. Cadmium would then bind with metallotionins, binds $\mathrm{Cd}+\mathrm{Mt}$, which would be deposited in the kidneys and induces the formation of lipid-free radical peroxidation that damages the kidneys, characterized by an increase of creatinine and $\beta 2$ microglobulins. This service aims to educate welding workers about the impact of cadmium intoxication on the body and the prevention against cadmium exposure. The methods used are demonstration and playback of a video about prevention against cadmium exposure. This activity was carried out on May 6 6 2021 at the CV. Rigansa Mataram welding workshop. The activity was attended by ten participants. The results are an increase of knowledge from a mean pretest score of 50 to a mean posttest score of 90 .
\end{abstract}

Keywords: cadmium, intoxication, welding workshop, workers, training.

Citation: Dirja, B.T., Rahmadhona, D., Zulkarnaen, D.A. (2021). Pelatihan pencegahan intoksikasi kadmium pada pekerja bengkel las di Kota Mataram. INDRA: Jurnal Pengabdian kepada Masyarakat, 2(2), 45-47. doi: https:// doi.org/10.29303/indra.v2i2.129

\section{Pendahuluan}

Kadmium (Cd) merupakan salah satu jenis logam berat yang berisiko besar bagi kesehatan manusia. Bertambahnya pencemaran logam berat sebanding dengan meningkatnya aktivitas yang dilakukan oleh manusia khususnya di bidang industri. International Agency for Research on Cancer (IARC) mengklasifikasikan $\mathrm{Cd}$ dalam kelompok I, yaitu bersifat karsinogenik pada manusia. Waktu paruh $\mathrm{Cd}$ yang panjang menyebabkan Cd sukar dieliminasi dari tubuh sehingga berpotensi menyebabkan gangguan kesehatan terutama kerusakan pada ginjal (Lauwerys, 1994).

Logam berat kadmium digunakan di berbagai bidang seperti pengelasan, bahan bakar, pelapisan logam, peleburan dan pemurnian zink (Zn), pewarna, baterai, minyak pelumas, pupuk dan pestisida (Palar, 2008., Chunhabundit, 2016). Kadmium pada pupuk dan pestisida dapat mencemari bahan pangan hasil produksi pertanian, sedangkan limbah cair hasil industri dapat mengalir mencemari sungai maupun laut.

Kadmium dapat masuk melalui jalur inhalasi dari polutan udara yang dihasilkan oleh aktivitas industri seperti proses pengelasan dan pemurnian logam. Kadmium juga dapat masuk melalui jalur oral, yaitu melalui makanan yang tercemar $\mathrm{Cd}$. Kadmium merupakan senyawa yang persisten di lingkungan dengan waktu paruh 30-40 tahun (Palar, 2008) sehingga paparan Cd baik akut maupun kronis sangat berbahaya bagi kesehatan manusia terutama terhadap organ ginjal, yang merupakan sasaran utama dari Cd. Kadmium yang masuk tubuh akan 
berikatan dengan protein metalotionin. Ikatan $\mathrm{Cd}$ dan metalotionin bersifat stabil dan dapat memicu peningkatan radikal bebas dalam hati dan ginjal sehingga dapat menimbulkan kerusakan pada kedua organ tersebut (Faroon et al., 2012)

Pekerja bengkel las merupakan kelompok yang beresiko terkena paparan $\mathrm{Cd}$. Penelitian Santoso dan Hernayanti (2016), menemukan kejadian hipertensi pada pekerja bengkel las di Purwokerto dari 40 probandus yang diperiksa kadar $\mathrm{Cd}$ darahnya ditemukan $72,5 \%$ mengalami hipertensi. Wohingati et al. (2014) menemukan adanya $\mathrm{Cd}$ dalam urin petani tanaman hias di Baturaden melebihi normal $(>2 \mu \mathrm{g} / \mathrm{L})$ dan disertai dengan penurunan Laju Filtrasi Glomerulus (LFG), hal ini menunjukkan adanya gangguan pada ginjal akibat paparan kadmium.

Proteksi pada pekerja dimulai dengan higiene personal dan kebiasaan kerja. Pemberian exhaust fan, ventilasi, dan alat pelindung diri berupa respirator dapat mengurangi pajanan. Kadar $\mathrm{Cd}$ di udara lingkungan kerja juga harus selalu dipantau. Pada area dengan partikel yang beterbangan, percikan kimia, radiasi panas (misalnya electroplating), harus digunakan pelindung mata, wajah, lengan, dan tangan, serta pakaian khusus yang tidak tembus. Fasilitas untuk membersihkan diri juga harus disediakan dan pekerja harus membersihkan diri sebelum makan dan sebelum pulang kerja. Tidak diperkenankan makan, minum, dan merokok di area kerja (Nordberg, 1998; Koutkia, 2003). Pemeriksaan prakerja harus meliputi riwayat penyakit paru dan ginjal sebelumnya. Pekerja yang sudah mempunyai gangguan tersebut harus dihindarkan dari pajanan $\mathrm{Cd}$ (Nordberg, 1998).

Pekerja bengkel las memiliki faktor resiko terpapar bahan aktif logam berat yaitu kadmium secara inhalasi. Pengabdian ini bermaksud membekali pekerja bengkel las dengan pengetahuan dan cara pencegahan terhadap kadmium saat bekerja.

\section{Metode Kegiatan}

Kegiatan ini dilakukan dengan menggunakan metode pelatihan. Sebelum pelatihan, terlebih dahulu dilakukan pengukuran tingkat pengetahuan peserta, untuk itu dilakukan pretest dan pada akhir kegiatan dilakukan posttest untuk mengetahui ketercapaian tingkat pengetahuan peserta. Pelatihan diberikan dalam bentuk penjelasan, demonstrasi dan pemutaran video singkat cara pencegahan terhadap kadmium saat bekerja.

\section{Hasil dan Pembahasan}

Pelaksanaan kegiatan adalah tanggal 6 Mei 2021 bertempat di Workshop bengkel las CV. Rigansa Kota Mataram. Kegiatan diikuti oleh 10 orang peserta. Kemudian diberikan pretest dan diberikan prinsip dasar tentang cara pencegahan terhadap kadmium saat bekerja. Pemutaran video untuk memvisualisasi cara pencegahan dan diperkuat dengan demonstrasi. Hasil pretest didapatkan rerata 50 dan setelah diberikan pemaparan dan dilakukan posttest didapatkan hasil 90. Tidak ada hambatan yang berarti untuk pelaksanaan tersebut, hanya saja beberapa peserta memiliki tingkat kecerdasan dan jenjang pendidikan yang berbeda.

Saran untuk pekerja bengkel las adalah selain menggunakan APD, mengonsumsi buah- buahan yang mengandung vitamin $C$ tinggi seperti wortel, tomat dan minum teh hijau yang mengandung antioksidan tinggi. Hal ini untuk mencegah paparan $\mathrm{Cd}$ yang dapat mengganggu fungsi ginjal.

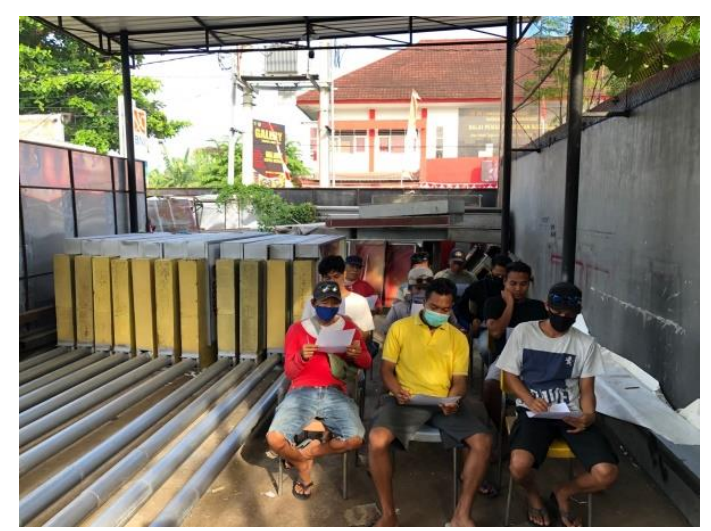

Gambar 1. Peserta mengerjakan pretest

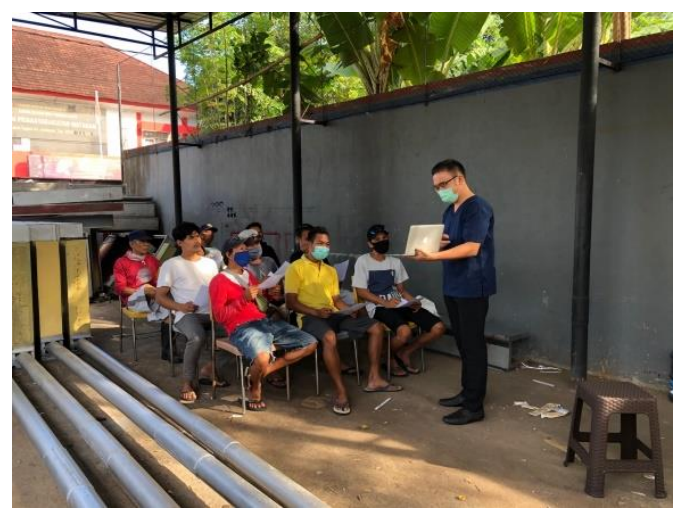

Gambar 2. Penjelasan tentang cara pencegahan terhadap kadmium 


\section{Kesimpulan dan Saran}

Pelatihan pencegahan intoksikasi kadmium pada pekerja bengkel las dilaksanakan pada tanggal 6 Mei 2021 dengan hasil berupa peningkatan pengetahuan dan cara pencegahan terhadap kadmium. Kegiatan ini sangat penting dilakukan secara berkala pada pekerja bengkel las di wilayah Kota Mataram.

\section{Ucapan Terima Kasih}

Penulis mengucapkan terima kasih kepada Universitas Mataram khususnya Fakultas Kedokteran yang telah memberi izin pengabdian ini. Ucapan terima kasih juga kami haturkan kepada Direktur CV. Rigansa yang telah memfasilitasi kegiatan ini.

\section{Daftar Pustaka}

Chunhabundit, R. (2016). Cadmium exposure and potential health risk from foods in contaminated area, Thailand. Toxicological Research, 32(1), 65-72.

Faroon, O., Ashizawa, A., Wright, S., Tucker, P., Jenkins, K., Ingerman, L., \& Rudisill, C. (2012). Toxicological profile of cadmium, agency for toxic substances and disease registry. Agency for Toxic Substances and Disease Registry (ATSDR) Toxicological Profiles.

Koutkia, P., \& Wang, R. Y. (2003). Electroplaters. In: M. I. Greenberg MI (Eds), Occupational, industrial, and environmental toxicology (2nd ed, pp. 126-141). Elsevier Health Sciences.

Lauwerys, R. R., Bernard, A. M., Roels, H. A., Buchet, J. P. (1994). Cadmium: exposure marker as predictors of nephrotoxic effects. Clinical Chemistry, 40(7) 1391-1394.

Nordberg, G. (1998). Metals: chemical properties and toxicity. In: J. M. Stellman (Ed), Encyclopaedia of occupational health and safety (4th ed). ILO.

Palar, H. (2008). Pencemaran dan toksikologi logam berat. PT Rineka Cipta Jakarta.

Peng, Q., Bakulski, K. M., Nan, B., \& Park, S. K. (2017). Cadmium and Alzheimer's disease mortality in U.S. adults: Updated evidence with a urinary biomarker and extended follow-up time. Environmental Research, 157, https://doi.org/10.1016/j.envres.2017.05.0 $\underline{11}$

Santoso, S dan Hernayanti. (2016). Efek paparan kadmium terhadap tekanan darah pekerja bengkel las. Paper presented at The Seminar Nasional Pengembangan Sumber Daya Pedesaan dan Kearifan Lokal Berkelanjutan VI Purwokerto, 24-25 November 2016.

Sasaki, T., Horiguchi, H., Arakawa, A., Oguma, E., Komatsuda, A., Sawada, K., Murata, K., Yokoyama, K., Matsukawa, T., Chiba, M., Omori, Y., \& Kamikomaki, N. (2019). Hospital-based screening to detect patients with cadmium nephropathy in cadmium-polluted areas in Japan. Environmental Health and Preventive Medicine, 24(1), $1-8$. https://doi.org/10.1186/s12199-019-0762-3

Wohingati. (2014). Pengaruh paparan kadmium (Cd) terhadap estimasi laju filtrasi glomerulus pada petani tanaman hias di Baturaden. [Unpublished thesis]. Universitas Jenderal Soedirman. 